\title{
GİRİŞİMCİLİK KURSLARINA KATILANLARIN TEMEL EĞİLİMLERİ ÜZERİNE BİR ARAŞTIRMA
}

\author{
Kurtuluş Yılmaz Genç*
}

öz

Bu çalışmanın amacı, Türkiye'de son dönemde yaygın şekilde görülen 'temel girişimcilik eğitimlerine' katılanların temel eğilimlerini Giresun, Trabzon ve Ordu'dan elde edilen veri kümesi temelinde ortaya koymaktır. Eser, girişimcilikle ilgili literatürü özetlemekte ve 196 kursiyerden oluşan bir örneklem üzerinden değerlendirmelere, farklı gruplar arasında karşılaştırmalara ve önerilere yer vermektedir. Buna göre, ilgili eğitimlere katılanların, ölçek kapsamında, esas olarak altı değişik eğilime sahip oldukları bulunmuştur: Dışa dönüklük - kendine güven, hazır olma - bilgili olma, kararlıık, atılımcılık, risk alma - girişimcilik, bağımsızlık. Bu değişkenler arasında bütünsel olarak yüksek düzeyli pozitif ilgileşim vardır. Buna ek olarak, veri analizi sonucunda katılımcıların yaşı ile 'dışa dönüklük - kendine güven' ve 'kararlılık' arasında pozitif ilişki saptanmıştır. Benzer şekilde, iş tecrübesiyle 'dışa dönüklük - kendine güven', 'kararlılık' ve 'atılımcılık' arasında istatistiksel olarak anlamlı pozitif ilgileşim olduğu görülmüştür. Aksine, eğitim düzeyi ile girişimcilik arasında anlamlı ilişki olmadığı belirlenmiştir. Diğer taraftan, 'iş tecrübesi' ile 'bağımsızlık' arasında istatistiksel olarak anlamlı, negatif ilişki vardır. Ek olarak, 'meslek' ile 'risk alma - girişimcilik' arasında istatistiksel olarak anlamlı, pozitif ilgileşim vardır.

Anahtar Sözcükler: Girişimcilik Kursları, Orta ve Doğu Karadeniz, Temel Girişimcilik Eğilimleri

\section{A RESEARCH ON THE PARTICIPATORS OF ENTREPRENEURSHIP TRAINING PROGRAMS TO IDENTIFY THEIR TENDENCIES}

\begin{abstract}
The aim of this study is to analyze the characteristics and tendencies of participators of the formal 'basic entrepreneurship trainings', which is a widespread activity in Turkey; with a sample from Giresun, Trabzon and Ordu. This study, examines the related literature, and includes evaluations, comparisons between groups, and suggestions depending on a sample of 196 participators. Accordingly, the tendencies of candidate entrepreneurs include six different dimensions: extroversion - self confidence, knowledge, determination,

\footnotetext{
* Giresun Üniversitesi, İktisadi ve İdari Bilimler Fakültesi, Giresun, E-posta: kyilmazgenc@gmail.com
} 


\section{Kurtuluş Yılmaz Genç}

progressiveness, risk taking, and independence. There are high levels of positive correlation among these variables. Moreover, the data analysis reveals that, there is statistically significant relationship between the age of respondents and their extroversion and determination. Again, it was found that, the job experience is significantly and positively associated with extroversion, determination, and progressiveness. In contrast, there is statistically significant but negative relationship between job experience and independence. On the other hand, no significant association was identified between education level and entrepreneurship tendencies. In addition, the 'job' is positively associated with risk taking.

Keywords: Entrepreneurship Training Programs, Central and Eastern Black Sea, Basic Entrepreneurial Tendencies

\section{GİRİŞ}

Girişimcilik eğitimleri dünyada yüz yıldan uzun bir zamandır sürmektedir. Toplumların gelişmesi için hayati bir önemde olan girişimcilik faaliyetleri devletler, sivil toplum örgütleri ve diğer birey veya unsurların destekleriyle gerçekleştirilebilmektedir. Ülkelerin ilerlemesinde, refahın artmasında esas bir unsur olan bu faaliyet, ekonomik istikrarın temel unsurlarının kurulup gelişimini ve sürekliliğini sağlamayı amaçlamaktadır.

Belli bir işte başarılı olmak için en temel unsurdan biri bu konuda bilgi sahibi olmaktır. Dünyada birçok ülkede, özellikle gelişmiş ülkelerde belli bir işe başlamak, o işi yapabilmek için eğitim almak, ilgili bir sertifika ya da diploma sahibi olmak gerekir. Bilgi sahibi olarak bir işe başlamak o işte başarı olasılığını artıracağı gibi, ortaya konulan ürünlerin ya da çıktıların da beklenilen niteliklere veya standartlara uygun olmasını sağlayacaktır. Başarılı işletmeler bir makro etki ile diğer sektörleri de olumlu etkileyecek ve ilişkili olarak ülke ekonomisini ve hatta günümüzün küreselleşmiş ekonomik sisteminde dünyanın diğer ekonomilerini de olumlu etkileyecektir.

Kurulan her bir işletme en azından bir kişi için istihdam olanağı yaratacaktır. Her bir yeni işletme ülkede toplam gelirin artmasına katkıda bulunacak, bu da talebin artmasını sağlayacaktır. Talebin artması üretimi daha da artıracak, üretimin artması da istihdamın yükselmesi ile birlikte gerçekleşebilecektir. İstihdamın ve üretimin artması geliri daha da artıracak, bu da toplam talep düzeyini yine yükseltecektir. Bu olumlu döngü giderek ekonominin büyümesini, devletin vergi gelirlerinin artmasını sağlayacaktır. Vergi gelirlerinin artışı da devletin daha kaliteli hizmet sağlaması, girişimciliği de olumlu etkileyecek şekilde alt yapının güçlendirilmesi sonuçlarını ortaya çıkaracaktır. Girişimcilik faaliyetlerinin 


\section{Girişimcilik Kurslarına Katılanların Temel Eğilimleri Üzerine Bir Araştırma}

başarılı şekilde sürdürülmesi, ekonominin büyümesi, istihdamın artışı devletin doğrudan desteklemek zorunda kalacağı insanların sayısını azaltacak, bir başka ifadeyle üzerindeki yükü hafifletecektir. İşte bu nedenlerle devletler, girişimciliği teşvik etmekte, doğrudan para desteği, altyapı desteği ve vergi indirimi gibi dolaylı katkılarla girişimciliğin geliştirilmesi yönünde politikalar uygulamaktadırlar.

Girişimcilik eğilimi değişik nedenlerle ortaya çıkmaktadır. Girişimcilik eğitimlerine katılanların durumu incelendiğinde bağımsız, kimseden talimat almadan çalışabilme arzusu, belli bir konuda bilgi sahibi olmak, para kazanmak ya da çok para kazanmak, saygınlığı artırmak, yapılabilecek başka bir işin olmaması, teşviklerin cazipliği, gibi nedenler insanları girişimciliğe yönlendirebilmektedir.

Türkiye'de girişimcilik kursları, Cumhuriyetin kuruluşundan bu yana, var olan işletme ya da girişim eksikliğini ortadan kaldırmak, toplumun intiyaçlarını karşılanması amacıyla devlet tarafından teşvik edilmektedir. Bir 'devlet kapitalizmi' uygulaması örneği olarak, devlet kendi kuruluşlarıyla temel intiyaçların bir kısmını karşılama yoluna giderken, daha fazlası için de bir özel sektörün ortaya çıkması ve başarıı olması için teşviki bir ulusal politika durumundadır.

Bu çalışmada Orta ve Doğu Karadeniz'de, Özellikle Giresun'da ve ayrıca, Ordu ve Giresun'da Küçük ve Orta Büyüklükte İşletmeleri Destekleme ve Geliştirme İdaresi Başkanlığı (KOSGEB)'in Giresun Üniversitesi ve Türkiye İş Kurumu (İŞKUR) ve diğer kamu kuruluşları ile birlikte düzenledikleri kurslara katılanların temel nitelikleri ve eğilimlerine ilişkin bir araştırmanın sonuçları ortaya konacaktır. Buna göre, ilk olarak ilgili ulusal ve uluslararası literatür ortaya konacak (ör.: Ahmetoglu, Leutner, Chamorro-Premuzic, 2011; Beaver, 2002; Hatten, 1997; İrmiş, Durak ve Özdemir, 2010; Kahya ve İmamoğlu, 2013; Karabulut, 2009; Lee, 1999; Megginson, Byrd ve Emeritus Megginson, 2000; Müftüoğlu ve Durukan, 2004; Stefanovic, Rankovic ve Prokic , 2014; Taşkın, 2012; Tiryaki, 2012; Uluköy, Demireli, Kahya, 2013; Vecchio, 2003) ardından alan araştırmasında elde edilen bulgular sunulacak ve değerlendirilecektir. Son olarak, bir değerlendirme ile birlikte çalışma son bulacaktır.

\section{İLGİLİ LİTERATÜRÜN DEĞERLENDİRİLMESİ}

Akademik olarak ilk olarak Fransız düşünür J. B. Say tarafından ortaya konan 'girişimci' (Ahmetoglu ve diğer, 2011; İrmiş ve diğer., 2010; Taşkın, 2012), Fransızca'da 'entreprende', İngilizce'de 'entrepreneur' terimiyle belirtilir ve 'girişmek', 'başlamak', 'el uzatmak' anlamına gelir. 


\section{Kurtuluş Yılmaz Genç}

Hatten (1997) girişimciyi 'bir işletmeyi kurmanın ve sürdürmenin finansal, maddi ve psikolojik risklerini üstlenerek bir iş fırsatının yaratabileceği getiriyi üstlenen kişi' olarak tanımlamaktadır. Bu tanımda, risklerin gerçekleşmesi durumunda ortaya çıkabilecek olumsuzluklar ile elde edilebilecek getiri girişimciliğin özünü oluşturmaktadır. Ancak, bunun yanında, yaratıcılık ve inovasyon girişimci davranışın diğer çok önemli unsurlarıdır. Diğer taraftan, sosyal girişimcilikte olduğu gibi, bu davranış işletmecilik dışı alanlarda da görülebilir.

Girişimcilik kavramı tarihsel süreç içerisinde iktisat literatüründe özellikle Schumpeter ve Marx'ın düşünceleriyle öne çıkmaktadır. Buna göre, bu iki yazar ve düşünür, Klasik ve Neo-Klasik kuramların 'çok sayıda küçük işletmenin kar etmeden varlığını sürdürdüğü denge içinde piyasalar' yaklaşımını kabul etmezler. Klasiklerin tam istihdam ve tam rekabet yaklaşımları dışında konuyu değerlendiren Marx, girişimciyi "kapitalist" olarak adlandırmakta ve esas olarak kar odaklı çalıştığııı belirtir. Bu çerçevede, kar elde etmek için "kapitalist" sürekli yeni teknoloji peşinde koşacaktır. Bu çaba, teknolojik ilerleme ve toplumsal değişim ile sonuçlanacaktır (Tiryaki, 2012). Görüldüğü gibi, Marx da girişimcinin toplumsal dönüşümdeki rolünü tespit etmiş ve kendi açısından yorumlamıştır. Bu durum, girişimcinin kapitalist ekonominin temeli olduğu gerçeğinin de ortaya konmasıdır.

Girişimciliğin 'yaratıcı yıkıcılık' olarak adlandırılması yine Klasik ve Neo-Klasik yaklaşımları kabul etmeyen Schumpeter'e dayanır. Schumpeter'e göre insanlık tarihi 'girişimcinin sürekli yaratıcı yıkıcılığının tarihidir'. Girişimci bu rolünü Klasiklerin iddiasının tersine taklit yolu ile değil, ona pazarda tekelci bir konum sağlayan 'icatçılığına' (yenilikçiliğine) borçludur (Tiryaki, 2012; Topkaya, 2013). Buna göre, Schumpeter de ekonomik ekonomik gelişmeyi doğrudan, temel aracı 'inovasyon' olan girişimcilerle ilişkilendirmektedir.

Beaver (2002)'e göre, insanların girişimci eğilimler göstermeleri psikolojik, ekonomik ve sosyolojik nedenlerle açıklanabilir (Beaver, 2002). Buna göre, psikolojik bakış çerçevesinde girişimcilik başarı intiyacı, kendilik kontrolü, risk-alma, bağımsızlığa düşkünlük ile yenilikçi ve yaratıcı eğilimler gibi özellikler ile açıklanabilir. Ekonomik yaklaşım da, yine girişimciliği ayırt edici bazı davranışlar ve özellikler ile açıklamakta ve bu tür faaliyetlerin ekonomi üzerindeki etkisine odaklanmaktadır. Benzer şekilde, sosyolojik yaklaşım da bir girişimcinin fırsatçı, maceraperest, hırslı, yenilikçi, öncü, üst düzeyde bir imaj yaratıcısı ve daha geniş bir finansal strateji uyarlama eğiliminde olması gerektiği düşüncesini 


\section{Girişimcilik Kurslarına Katılanların Temel Eğilimleri Üzerine Bir Araştırma}

içermektedir. Müftüoğlu ve Durukan (2004) da, girişimciliğin sosyal ve kültürel bir olgu olduğunu ifade etmektedirler.

Girişimcilik konusundaki yaklaşımlara ilişkin bir başka sınıflandırma bireysel, çevresel ve firma temelinde bakış çerçevesindedir (İrmiş ve diğer., 2010). Buna göre, 'bireysel yaklaşım' girişimciliği bireysel özelliklerle ilişkilendirerek açıklamaktadır. Kişilik özellikleri, eğitim, ailede bir girişimcinin olup olmaması gibi durumlar girişimciliğe geçiş konusunda belirleyici olacaktır. Çevresel yaklaşım, girişimciliğin ortaya çıkmasında çevresel etkenlerin ve özellikle de kültürün önemine odaklanır. Bunun yanı sıra, ekonomik yapı, devlet politikaları gibi olgular da girişimcilik üzerinde daha çok etkide bulunan çevresel unsurlar olarak ele alınmıştır. Firma yaklaşımı ise, girişimcinin özellikleri ile firmanın yaşam evreleri arasında doğrudan bir bağ kurmaktadır. Buna göre, girişimci fırsatlara odaklı, yaratıcı, yenilikçi, karlıı̆ı amaçlayan bağımsız bir kişilik olarak varlığını devam ettirdikçe kurulu işletme de bir 'girişim' olma durumunu sürdürecektir. Bir başka ifade ile, 'girişimci' nitelik korunmall, ancak, 'tatmin olan yönetici', 'hayal kırıklığına uğraya yönetici' ve 'klasik bürokrat' olma durumları dikkatle değerlendirilmeli (İrmiş ve diğer., 2010), sorgulanmalı ve ilgili aşamaların yaratacağı olumsuzluklardan olabildiğince uzak durulmalıdır. Böylece, işletme rekabette öne çıkabilecek, karlıık ve büyüme amaçlarına ulaşabilecektir.

Megginson ve diğer. (2000), girişimciliğin sınır tanımadığını, insanların her yaşta girişimci olabileceklerini ifade etmektedirler. Yazarlar, küçük işletmelerin yaşlılara da yeni fırsatlar ve esneklik sağladığını belirtmektedirler. Kaldı ki, girişimcilik insanlara günün istedikleri saatinde açabilecekleri ve kapatabilecekleri, istedikleri gibi tasarlayabilecekleri bir işyeri sağlamaktadır. Yine, girişimciliğin yaratıcılık, inovasyon, risk üstlenme, genel yönetim ve yüksek performans beklentisi gibi bileşenleri belirleyicidir (Hatten, 1997; Lee, 1999). Buna göre, inovasyon, bir ürüne, sürece, pazara, maddeye ya da örgüte ilişkin olabilir. Risk, olası kayıplar ya da işin başarısız olmasına ilişkindir. Genel yönetim, işletmenin yürütülmesi ve işletme için gerekli kaynakların tahsisi işlevidir. Son olarak, performans özlemi, yüksek düzeylerde büyüme ve karlılık beklentisini yansitır.

Megginson ve diğer. (2000) girişimciliğin bağımsızlık isteği, belli bir süreci başlatabilme ve sonuçlandırabilme, başarılı olma isteği, ailevi ve kişisel nedenler, hızı ve çabuk sonuç beklentisi, hızlı bir şekilde yanıt verebilme, kendini işine adama, girişimciliğe tasarlayarak ya da şansla başlamanın bir sonucu olduğunu ifade etmektedirler. Benzer şekilde, 


\section{Kurtuluş Yılmaz Genç}

Müftüoğlu ve Durukan (2004), girişimcilerin "yıkıcı yaratıclık"la ekonomik büyümenin en önemli aktörü olduklarını vurgulamaktadırlar. Buna göre, söz konusu yıkıcı yaratıcılık, yeni tedarik kaynakları, yeni satış piyasaları, yeni ürünler, yeni süreçler ve yeni örgütsel şekiller ortaya koyarak eskinin yerine koymayı ifade etmektedir.

Megginson ve diğer. (2000), insanlara hizmet etme, karlılık odağı, çevreyi koruma gibi sosyal amaçlar ve büyüme odağının insanları işletme kurmaya yönlendirdiğini ifade etmektedirler. Literatür girişimcilik için en önemli beş unsurun ("big five") risk üstlenme, başarı intiyacı, özerklik intiyacl, kişisel fayda ve kendilik kontrolü olduğunu belirtmektedir (Vecchio, 2003: 306). Stefanovic ve diğer. (2011) girişimcilerin kendi patronu olma, deneyimler ve eğitimden faydalanabilme, kendini kanıtlama, geliri artırma, aile üyelerine çalışma olanakları yaratma, kişisel tatmin ve büyüme, iş güvencesi elde etme, kişisel özgürlüğü sürdürebilme, aileye daha yakın olma ve 'eğlence olsun diye' gibi gerekçelerle bir işletme kurduklarını belirlemişlerdir.

Müftüoğlu ve Durukan (2004)'e göre, girişimcilerin evrensel özelliklerinin yanı sıra, yerel nitelikleri de önemlidir. Bu çerçevede, girişimcilik konusundaki çalışmalar, uygulamalar konunun bu yönünü de dikkate almalıdırlar.

Girişimci eğilimlerin ortaya çıkısında aile, çevre ve eğitim önemlidir. Girişimcilik düzeyinin ülkeden ülkeye, kültürden kültüre değişmesi bu durumun bir kanıtı olarak değerlendirilebilir (Lee, 1999). Girişimci kişiliğin ortaya çıkmasında yaş, cinsiyet, eğitim, ailenin tutumu ve başarı güdüsü önemli etkenlerdir (Taşkın, 2012). Girişimcilerin önemli bir kısmının özellikle gençken girişimci davranışlar sergilemeleri, cinsiyete, eğitim düzeyine, ailenin tutumuna bağlı olarak girişimcilik eğilimlerinin değişebilmesi söz konusu değişkenlerin önemini ortaya koyarsa da, bu unsurların etkisinin durumdan duruma değişebileceği ve bazı kültürlerde hiç etkili olmayabileceği açıktır. Buna göre, dünyanın farklı ülkelerinde farklı girişimci özelliklerinin öne çıkabileceği değerlendirilebilir.

Literatürde yer alan ampirik çalışmalarda farklı değişkenlere ilişkin ilginç sonuçlara ulaşılabilir. Kahya ve İmamoğlu (2013) yaptıkları çalışmada, cinsiyet ile belirsizliğe tolerans, medeni durum ile risk alma ve eğitim düzeyi ile risk alma ve başarma intiyacı arasında istatistiksel olarak anlamlı farklılıklar tespit etmişlerdir. Öte yandan, Karabulut (2009), girişimcilik eğitimi alan öğrencilerin kendi işini kurma eğilimlerinin düşük olduğunu bulmuştur. Uluköy ve diğer. (2013), KOSGEB tarafından düzenlenen 'temel girişimcilik eğitimleri'ne katılanlar üzerine yaptıkları araştırmada sonucunda, ilgili eğitimlerin girişimcilik bilincinin oluşumuna, 


\section{Girişimcilik Kurslarına Katılanların Temel Eğilimleri Üzerine Bir Araştırma}

özgüvenin artmasına ve risk alma eğiliminin artışına katkı sağladığı sonucuna ulaşmışlardır. Dönmez Polat (2011), işletme sahip yöneticisinin eğitimi ile girişimcilik motivasyonu arasında istatistiksel olarak anlamlı pozitif ilişki bulmuştır. Ali, Topping ve Tariq (2011), farklı bir boyutta, ebeveynelerin eğitimi ile çocukların (öğrencilerin) girişimciliği bir meslek olarak tercihleri arasında anlamlı pozitif ilişki bulmuşlardır. Okhomina (2015), destekleyici çevrenin, psikolojik özellikler ile girişimci yönelim arasındaki ilişkiyi etkilediğini bulmuştur. Bu sonuç, ailede girişimci kişi ya da kişilerin bulunmasının girişimcilik eğilimleri üzerindeki rolü bakımından dikkate değerdir.

\section{Hipotezler}

Girişimcilik kursuna katılanlar genel olarak elli yaş altındaki insanlardır; nadiren bu yaşın üzerinde bu kursiyere rastlanmaktadır. Günümüzde girişimciliğin özellikle gençler arasında çok cazip konu olduğu açıktır. Her eğitim seviyesinden ve toplumun her kesiminden gençler konuya ilgi göstermektedirler. Bu çerçevede girişimciliğin genellikle gençlerin daha çok görüldüğü bir alan olarak değerlendirmek yanlış olmayacaktır. Kuşkusuz, bu durum toplumun nüfus yapısı, yaş dağııımı ve fiziksel nitelikler ile de ilişkilidir. Diğer taraftan, yaratıclı̆̆ın bilgi birikiminin bir sonucu olduğu ve yaş ilerledikçe bu birikimin arttığı düşünülebilir. Bunu dengeleyen ise, genç yaşlarda risk alma eğiliminin ve fırsatları değerlendirebilmenin daha güçlü bir şekilde ortaya çıkmasıdır.

Buna göre:

H1 : Katıımcıların yaşı ile genel girişimcilik eğilimi arasında pozitif ilişki vardır.

Dünya'da ve Türkiye'de genel girişimcilik profili incelendiğinde görülecektir ki; her eğitim düzeyinden çok başarılı girişimciler vardır. Türkiye'de özellikle büyük kentlerde çok başarılı, genç, üniversite mezunu girişimci gençlere yoğun olarak rastlanabilir. Ancak toplumun, geneline bakıldığında hiç eğitim görmese de çok üst düzeyde başarılı olmuş girişimci örnekleri çoktur. Sanayi ve Ticaret Odaları'nın üye profilinden de bu durum belirlenebilir. Öte yandan, dünyada en çok tanınan, takdir edilen girişimcilerin çoğunun üniversite okumamış, ya da üniversiteyi terk etmiş kişiler olduğu bilinmektedir. Türkiye'de de benzer bir durum gözlenebilir. Düşük eğitim düzeylerinden gelen kişiler için, 'var olma'nın ya da saygın olmanın en önemli yollarından biri girişimci olmaktır. Bu kesimden gelen kişiler daha çok risk alır ve bir kısmı yüksek riskle orantılı olarak çok başarıı olur. Bu çerçevede: 


\section{Kurtuluş Yılmaz Genç}

H2: Kursiyerlerin girişimcilik eğilimleri eğitim durumlarından bağımsızdır.

Çalışma alanlarının farklılaşmasıyla girişimcilik eğilimi ilişkilendirilebilir. Bunun dışında, belli alanlardan gelen kişilerin daha girişimci özellikler sergileyebilecekleri öngörülebilir. İmalat sanayinde uzun yıllar çalışmış kişilerin bir yenilik ortaya koyarak kendi işletmelerini kurmaları bu duruma örnek gösterilebilir. Bunun yanı sıra, başarı, büyüme ve karlılık olasılığı sektörden sektöre değişebilir. Buna göre, çalışılan sektör risk alma, yaratıcılık ve firsatlardan yaralanabilmeyi etkileyebilir. Dolayısıyla:

H3 : Kursiyerlerin girişimcilik eğilimleri ile çalışma alanları arasında pozitif ilişki vardır.

İş tecrübesinin bilgi birikimini artırmasından dolayı risk alma eğilimini güçlendireceği, bunun da, girişimcilik davranışını olumlu etkileyeceği söylenebilir. Yine, iş tecrübesi fırsatlardan yaralanabilme, dışa dönüklük, kendine güven, kararlılık, atılımcılık, bağımsızlık, sonuca ulaşabilme ve liderlik gibi bir girişimcide bulunması gereken temel niteliklerin kazanılmasını kolaylaştırabilir. Elde edilen deneyim hatalardan sakınmayı, aynı hataları tekrar yapmamayı sağlayabilir. Bu durum girişimci tutumlar edinmeyi güçlendirecektir. Sonuçta, iddia edilebilir ki:

H4: Kursiyerlerin iş tecrübesi ile girişimcilik eğilimleri arasında pozitif ilişki vardır.

Katılımcıların daha önce bir işletme kurmuş olmaları, iş tecrübesi için yukarıda ifade edilenlerle benzer sonuçları doğurabilir. Var olan işletme ile piyasa koşulları hakkında bilgi sahibi olunacaktır. Pazardaki fırsatlar hakkında daha kolay bilgi edinilebilecektir. İnsanların talep ettiği mal ve hizmetler nelerdir? Bunlara en uygun şekilde nasıl yanıt verilebilir? Gibi sorular bir girişimci bakış açısıyla daha kolay yanıtlanabilir. Buna göre katılımcılar daha önce bir işletme kurmuşlarsa, girişimcilik eğilimleri daha yüksek olmalıdır.

H5: Kursiyerler daha önce bir işletme kurmuşlarsa girişimcilik eğilimleri daha yüksek olacaktır.

Açıkça bilinmektedir ki; girişimcilik her meslek dalında olanaklıdır. Her meslek alanı yaratıclığa, yenilikçiliğe açıktır ve riske dayalı fırsatlar barındııı. Benzer şekilde, girişimciler kendine güvenle, kararlııkla, ileri görüşlülükle, planlı hareket ederek ve çevreye öncülük ederek ya da en azından uyarak her alanda başarılı olabilirler. Her meslek alanında dünyanın farklı yerlerindeki gelişmeler aktarılabilir, uygulanabilir. Yeni pazarlar her alanda bulunabilir ya da oluşturulabilir. Yine, sürekli değişim 


\section{Girişimcilik Kurslarına Katılanların Temel Eğilimleri Üzerine Bir Araştırma}

evrendeki temel yasadır. Bu çerçevede, meslek ile girişimcilik eğilimi birbirinden bağımsız olmalıdır.

H6: Örneklem dâhilinde, meslek ile girişimcilik eğilimi birbirinden bağımsızdır.

Medeni durum farklı psikolojik sonuçlarla ilişkilendirilebilir. Evli olup olmama aşıı riskler alma ya da aşırı temkinli hareket etme gibi davranışlara yol açabilir. Medeni durumun girişimcilik eğilimi üzerindeki etkisi de elbette psikolojik bir etkidir. İnsanlar, işlerindeki bir başarısızıktan dolayı evlilik yaşamlarını tehlikeye atmaktan özellikle kaçınabilirler. Tersine, mevcut refah koşullarını iyileştirmek için büyük riskler de alabilirler. Bu durum, bireyden bireye, koşuldan koşula değişebilecektir. Başka bir ifadeyle yerel farklılıklar olasıdır.

H7: Örneklem dâhilinde, girişimcilik eğilimi medeni durumdan bağımsızdır.

Bir başka psikolojik etken çocuk sayısı olabilir. Çocuk sayısı da yine medeni durum gibi temkinli hareket etme ya da risk almayı beraberinde getirebilir. Buna karşın, yine çevresel koşullar bu değişkenin etkisini artırıp azaltabilir. Örnek olarak, aile bağlarının çok güçlü olmadığı toplumlarda çocuk sayısı girişimci davranışı etkileyen bir unsur haline gelmeyebilir. Böyle bir durumda, ebeveyn risk düzeyi çok yüksek girişimci davranışlar sergileyebilir. Diğer taraftan, aile bağlarının güçlü olduğu toplumlarda iki eğilim gözlemlenebilir: Temkinlilik ya da yüksek riskli davranışlar. Anne ya da baba, çocukların mevcut refah durumlarını sarsacak eğilimlerden özellikle kaçınabilecekleri gibi, durumu daha da iyi bir seviyeye getirebilmek için çok atııımc davranışlar sergileyebilirler. Dolayısıyla, ülke düzeyinde, yerel, bölgesel durumlar test edilmelidir.

H8: Kursiyerlerin çocuk sayısı ile girişimcilik eğilimleri birbirinden bağımsızdır.

\section{Araştırması, Metodoloji ve Araştırmanın Amacı}

Bu çalışmada, Küçük ve Orta Büyüklükte İşletmeleri Destekleme ve Geliştirme İdaresi Başkanlığı (KOSGEB) gözetiminde, denetiminde düzenlenen 'Uygulamalı Girişimcilik Eğitimi' programlarına katılan kursiyerlerin (halen girişimci olanlar ve girişimci adayları) temel nitelikleri (demografik veri) ve girişimcilik eğilimleri arasındaki ilişkileri ortaya koymak amaçlanmaktadır. Bunun yanında, bu çalışma ile girişimcilik ve 'girişimcilik kursları'na ilişkin değerlendirmeler ile ilgili konulara katkıda bulunmak amaçlanmaktadır. 


\section{Kurtuluş Yılmaz Genç}

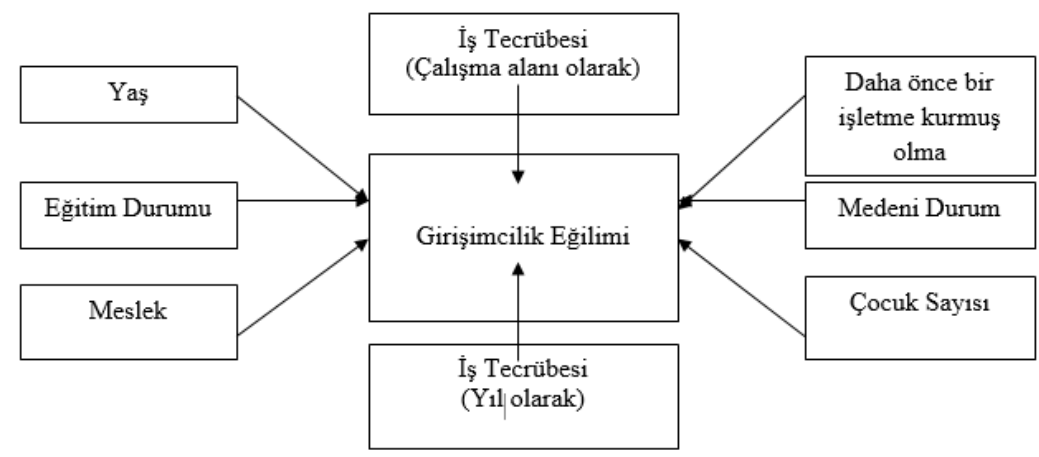

Şekil 1. Araştırma Modeli

\section{Örneklem ve Veri Toplama}

Araştırma kapsamında, Giresun Merkez, Eynesil ilçesi ve Trabzon Merkez (Ortahisar) ve Ordu Merkez (Altınordu)'da verilen 'uygulamalı girişimcilik eğitimleri'ne katılanlara uygulanan anket formlarıyla veri elde edilmiştir. Bu çerçevede örneklem 196 kişiden oluşmaktadır. Bir başka ifadeyle, toplam 196 geçerli anket formu elde edilmiştir. Araştırma örneklemine dâhil olanların 90 farklı çalışma alanından ve 78 farklı meslekten geldikleri (farkı iş yaptıkları) tespit edilmiştir. Elde edilen veri kümesi istatistik paket programı (SPSS) ile analiz edilmiş ve 20 olası ilişki sınanmıştır. Veri kümesinin normal dağılım göstermemesinden dolayı, Korelasyon (Spearman) ve Mann Whitney U, Kruskal Wallis gibi parametrik olmayan testler kullanılmıştır. Anket soruları ilgili literatürden, özellikle 'Marmara Girişim'in ölçeği örnek alınarak (www.marmaragirisim.com); Karabulut (2009) ve yine adı tespit edilemeyen bir yazarın kullanmış olduğu ölçekten yararlanılarak oluşturulmuştur. Anket formunda 48 öğe ve 7 demografik öğe yer almıştır.

\section{Araştırmanın Kısıtları}

Araştırma yalnızca 'Uygulamalı Girişimcilik Eğitim'lerine katılanlarla sınırıdır. Bir başka kısıt da, verinin yalnızca Giresun, Ordu ve Trabzon'da toplanmış olmasıdır. Elde edilen verinin yalnızca kişisel ifadeye (beyana) dayalı olması da bir başka sınırlıık olarak değerlendirilebilir. Ayrıca, veri ancak parametrik olmayan istatistiksel analizler için uygundur. 


\section{Girişimcilik Kurslarına Katılanların Temel Eğilimleri Üzerine Bir Araştırma}

\section{BULGULAR}

Anket formunda yer alan değişkenler altı faktör altında toplanmıştır: Dışa dönüklük - kendine güven (beş öğe), hazır olma bilgili olma (altı öğe), kararlılık (beş öğe), atılımcılık (beş öğe), risk alma girişimcilik (beş öğe), bağımsızlık (üç öğe). Güvenilirlik analizi sonuçlarına göre bütün ölçekler güvenilirdir (Cronbach Alfa $>, 70$ ).

Demografik sorulara verilen yanıtlara göre; katılımcıların 17'si $(\% 8,67)$ ilkokul, 34'ü $(\% 17,34)$ ortaokul, 83'ü (\% 42,34) lise, 59'u $(\% 30,1)$ üniversite ve 3 'ü $(\% 1,5)$ de lisansüstü öğrenim düzeyinde diplomaya sahiptir (Tablo 1). Katılımcıların ağırlıklı olarak lise ve üniversite (lisans ve ön lisans) mezunu oldukları görülmektedir. Bunun yanında, ortaokul mezunlarının oranı da kayda değer düzeydedir. Beklenebileceği gibi, lisansüstü öğrenim düzeyinde oldukça az katıımcı vardır.

Tablo 1. Katılımcıların Eğitim Durumu

\begin{tabular}{cll}
\hline $\begin{array}{c}\text { Eğitim } \\
\text { Düzeyi }\end{array}$ & $\mathbf{N}$ & $\mathbf{\%}$ \\
\hline İlkokul & 17 & 8,67 \\
Ortaokul & 34 & 17,34 \\
Lise & 83 & 42,34 \\
Üniversite & 59 & 30,1 \\
Lisansüstü & 3 & 1,5 \\
\hline
\end{tabular}

Anketi yanitlayan kursiyerlerin $51^{\prime i}$ (\%26) daha önce bir işletme kurmuştur (Tablo 2). Belli bir konudaki deneyim kuşkusuz ilgili alandaki başarı olasılığını yükseltecektir. Diğer taraftan katıımcıların büyük çoğunluğunun $(\% 73,97)$ daha önce bir işletme kurmamış olmaları verilen yanıtların niteliği açısından önemlidir.

Tablo 2. Katılımcıların Daha Önce Bir İşletme Kurmuş OIma Kurma Durumu

\begin{tabular}{|c|c|c|c|}
\hline $\begin{array}{l}\text { İşletme } \\
\text { Olma }\end{array}$ & Kurmuş & $\mathbf{N}$ & $\%$ \\
\hline Evet & & 51 & 26,03 \\
\hline Hayır & & 145 & 73,97 \\
\hline
\end{tabular}

Katılımcıların demografik özellikleri ile ilgili bir başka sonuç da medeni durumları ile ilgilidir. Buna göre, örneklemi oluşturanların $111^{\prime} \mathrm{i}$ $(\% 56,63)$ evli, $145^{\prime} \mathrm{i}(\% 43,36)$ bekardır (Tablo 3). Bu iki oranın birbirinden çok da uzak olmadığı görülmektedir. 
Kurtuluş Yılmaz Genç

Tablo 3. Katılımcıların Medeni Durumu

\begin{tabular}{|c|c|c|}
\hline $\begin{array}{ll}\text { Evli } & \text { Olup } \\
\text { Olmama } & \end{array}$ & $\mathbf{N}$ & $\%$ \\
\hline Evli & 111 & 56,63 \\
\hline Bekar & 85 & 43,36 \\
\hline
\end{tabular}

Tablo 4, faktör analizi sonuçlarını ortaya koymaktadır. Araştırma kapsamında, değişkenler altı faktör altında toplanmıştır. Genel olarak ölçekler güvenilirdir: Dışa dönüklük - kendine güven (.8083); hazır olma - bilgili olma (,7613); kararlılık (,7578); atılımcllık (,8441); risk alma girişimcilik (,6386); bağımsızıı (,5406).

Temel değişkenler ile yaş ve iş tecrübesi arasındaki ilişki Tablo 5 'te ortaya konmuştur. Buna göre, katıımcıların yaşı ile 'dışa dönüklük kendine güven' $(, 158 ;, 027)$ ve 'kararlıık' $(, 179 ;, 012)$ arasında düşük düzeyde, istatistiksel olarak anlamlı pozitif ilişki vardır. Benzer şekilde, iş tecrübesiyle 'dışa dönüklük - kendine güven' $(, 166 ;, 020)$; 'kararlıık' $(, 176 ;, 014)$ ve 'atılımcilık' $(, 178 ;, 012)$ arasında istatistiksel olarak anlamlı pozitif ilgileşim vardır. Diğer taraftan, 'dışa dönüklük - kendine güven' ile 'hazır olma - bilgili olma' (,399; ,000); 'kararlıık' (,370; ,000); 'atılımclık' (,393; ,000); 'risk alma - girişimcilik' $(, 435 ;, 000)$ ve 'bağımsızlık' $(, 169 ;, 018)$ arasında yine istatistiksel olarak anlamlı pozitif ilgileşim vardır. Girişimcilikle ilgili değişkenlerin bir bütünlük göstermeleri, birbirleriyle doğrusallık göstermeleri önemlidir. Buna göre $\mathrm{H}_{1}$, kısmen kabul edilmiştir. $\mathrm{H}_{4}$ kısmen kabul edilmiştir.

Tablo 4. Faktör Analizi ve Güvenilirlik Analizi Sonuçları

\begin{tabular}{lll}
\hline Değişkenler & Faktör & Alfa \\
& Değerleri & Değeri
\end{tabular}

KMO : .859

Anlamlılık : .000

Serbestlik Derecesi: 1128

Açıklanan Toplam Varyans: $\mathbf{5 0 . 3 7 7}$

\section{D1. Dışa Dönüklük -Kendine Güven}

G18. Sosyal çevre edinmek benim için çok kolaydır.

G19. İnsanlarla bir arada olmaktan ve onlarla ,732 ilgilenmekten memnuniyet duyarım.

G17. Kolaylıkla yeni ilişkiler kurar ve sürdürürüm.

G1. Önceliğim kendi işimi kurmaktır. $\quad$,526

G24. İnsanlarla birlikteyken ve işimde kendime ,503

güvenim tamdır. 


\section{Girişimcilik Kurslarına Katılanların Temel Eğilimleri Üzerine Bir Araştırma}

\section{D2. Hazır Olma - Bilgili Olma}

G43. İş kurmadan önce, öncelikli olarak iş planı , 675 hazırlanmalıdır.

G5. İşimle bizzat ilgilenmekten ve sorumluluk almaktan , 580 zevk alırım.

G41. Girişimcilik son derece saygın bir çalışma alanıdır.

G13. Başarısız olduğumda bir daha aynı durumu yaşamamak için nedenleri ortaya çıkarma çabasına girerim.

G7. Sağlıklıyım ve yüksek morale sahibim.

G42. İşi kurmak ve başarılı şekilde sürdürmek için öncelikli olan iş fikridir.

\section{D3. Kararlılık}

G9. Karmaşık durumları analiz edip çözümler üretmekten zevk alırım.

G3. Sorunları çözerken yaratıcılık önceliğimdir.

G10. Karmaşık sorunları çözmek benim için zevktir.

G4. Bir işe başlayınca tamamlayana kadar bırakmam.

,553

G25. Başardıkça ailemin gururu olacağıma eminim.

\section{D4. Atılımcılık}

G29. Ekonomik bağımsızlık için herhangi bir işi ilk ben başlatabilirim.

G28. Verdiğim kararların çevredekilerin kararlarına göre en iyisi olduğuna inanırım.

G27. 'Yapılamayacak iş yoktur' anlayışı son derece doğrudur.

G30. Rasyonel davranış neyi gerektiriyorsa onu

G26. Akla gelen her soru anlamlıdır, sorulmalıdır.

\section{D5. Risk Alma- Girişimcilik}

G39. Yeni yollar denemek beni ürkütmez.

G35. Hiçbir tehlike beni yıldıramaz.

G33. Yeni olanı her zaman denerim.

G40. Bir konuda ilk ya da öncü olmaktan kaçınmam.

G38. Yabancılarla kolaylıkla ilişki kurarım.

\section{D6. Bağımsızık}

G14. Kararlarımı kendim verir ve savunurum. 


\section{Kurtuluş Yılmaz Genç}

Tablo 5. Temel Değişkenlere İlişkin Korelâsyon Analizi Sonuçları

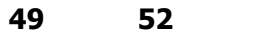

1

2

3

4

\begin{tabular}{|c|c|c|c|c|c|c|c|}
\hline \multirow{2}{*}{\multicolumn{8}{|c|}{ G49. Yas }} \\
\hline & & & & & & & \\
\hline $\begin{array}{l}\text { G52. } \dot{I S} \\
\text { Tecrübesi } \\
\text { (yıl olarak) }\end{array}$ & $\begin{array}{c}483 * * \\
000\end{array}$ & & & & & & \\
\hline $\begin{array}{l}\text { T1. Dışa } \\
\text { Dönüklük } \\
\text { - Kendine } \\
\text { Güven }\end{array}$ & $\begin{array}{l}158^{*} \\
027\end{array}$ & $\begin{array}{r}166 * \\
020\end{array}$ & & & & & \\
\hline $\begin{array}{l}\text { T2. Hazır } \\
\text { Olma - } \\
\text { Bilgili } \\
\text { Olma }\end{array}$ & $\begin{array}{l}132 \\
065\end{array}$ & $\begin{array}{l}108 \\
133\end{array}$ & $\begin{array}{c}399 * * \\
000\end{array}$ & & & & \\
\hline $\begin{array}{l}\text { T3. } \\
\text { Kararlılık }\end{array}$ & $\begin{array}{l}179 * \\
012\end{array}$ & $\begin{array}{r}176 * \\
014\end{array}$ & $\begin{array}{c}370 * * \\
000\end{array}$ & $\begin{array}{c}350 * * \\
000\end{array}$ & & & \\
\hline $\begin{array}{l}\text { T4. } \\
\text { Atılımcılık }\end{array}$ & $\begin{array}{l}139 \\
052\end{array}$ & $\begin{array}{r}178^{*} \\
012\end{array}$ & $\begin{array}{c}393 * * \\
000\end{array}$ & $\begin{array}{c}393 * * \\
000\end{array}$ & $\begin{array}{c}389 * * \\
000\end{array}$ & & \\
\hline $\begin{array}{lr}\text { T5. } & \text { Risk } \\
\text { Alma } & - \\
\text { Girişimcilik }\end{array}$ & $\begin{array}{l}022 \\
761\end{array}$ & $\begin{array}{l}124 \\
084\end{array}$ & $\begin{array}{c}435^{* *} \\
000\end{array}$ & $\begin{array}{c}278 * * \\
000\end{array}$ & $\begin{array}{c}303 * * \\
000\end{array}$ & $\begin{array}{c}528 * * \\
000\end{array}$ & \\
\hline $\begin{array}{l}\text { T6. } \\
\text { Bağımsızlık }\end{array}$ & 134 & 048 & $169 *$ & $195^{* *}$ & 087 & $283 * *$ & $233 * *$ \\
\hline & 061 & 501 & 018 & 006 & 223 & 000 & 001 \\
\hline
\end{tabular}

** Korelasyon ,01 düzeyinde anlamlıdır. * Korelasyon ,05 düzeyinde anlamlıdır.

Eğitim düzeyi ile girişimcilik eğilimleri arasındaki ilişki Tablo 6'da ortaya konmuştur. Buna göre, bu iki değişken arasında istatistiksel olarak anlamlı ilişki yoktur ( $x^{2}[\mathrm{df}=4, \mathrm{n}=194]=1,885$ ve anl.>0,05). Türkiye'de çok başarılı girişimcilerin çok farklı eğitim düzeylerinden gelebilmeleri bulunan bu sonucu destekler bir gerçekliktir. $\mathrm{H}_{2}$ kabul edilmiştir. 
Girişimcilik Kurslarına Katılanların Temel Eğilimleri Üzerine Bir Araştırma

Tablo 6. Eğitim Düzeyi ile Girişimcilik Eğilimleri İlişkisi (Kruskal - Wallis Testi Sonucu)

\begin{tabular}{llllll}
\hline $\begin{array}{l}\text { Eğitim } \\
\text { Düzeyi }\end{array}$ & $\mathbf{N}$ & $\begin{array}{l}\text { Ortalama } \\
\text { Aralığı }\end{array}$ & Sd. & $\mathbf{X}^{2}$ & Anlamlılık \\
\hline İlkokul & 17 & 97,53 & 4 & 1,885 &, 757 \\
Ortaokul & 32 & 92,28 & & & \\
Lise & 83 & 96,13 & & & \\
Üniversite & 59 & 103,75 & & & \\
Lisansüstü & 3 & 68,00 & & & \\
\hline
\end{tabular}

Tablo 7. Tecrübe, Meslek ve Çocuk Sayısı ile Girişimcilik Eğilimleri İliş̧kisi (Korelâsyon Analizi)

\begin{tabular}{|c|c|c|c|c|c|c|c|c|}
\hline & G51 & G54 & G56 & T1 & T2 & T3 & T4 & T5 \\
\hline $\begin{array}{l}\text { G51. İş } \\
\text { Tecrübesi } \\
\text { (çalışma al.) }\end{array}$ & & & & & & & & \\
\hline $\begin{array}{l}\text { G54. } \\
\text { Meslek }\end{array}$ & $\begin{array}{l}\text {,350** } \\
, 000\end{array}$ & & & & & & & \\
\hline $\begin{array}{l}\text { G56. Çocuk } \\
\text { SayıSI }\end{array}$ & $\begin{array}{l}, 046 \\
, 519\end{array}$ & $\begin{array}{l}- \\
, 197 * * \\
, 006\end{array}$ & 1 & & & & & \\
\hline $\begin{array}{l}\text { T1. Dişa } \\
\text { Dönüklük - } \\
\text { Kendine } \\
\text { Güven }\end{array}$ & $\begin{array}{l}, 093 \\
196\end{array}$ & $\begin{array}{l}, 074 \\
, 300\end{array}$ & $\begin{array}{l}, 048 \\
, 500\end{array}$ & 1 & & & & \\
\hline $\begin{array}{lr}\text { T2. } & \text { Hazır } \\
\text { Olma } & - \\
\text { Bilgili Olma }\end{array}$ & $\begin{array}{l}-081 \\
261\end{array}$ & $\begin{array}{l}118 \\
, 098\end{array}$ & $\begin{array}{l}, 098 \\
172\end{array}$ & $\begin{array}{l}\text {,399** } \\
, 000\end{array}$ & 1 & & & \\
\hline $\begin{array}{l}\text { T3. } \\
\text { Kararlılık }\end{array}$ & $\begin{array}{l}028 \\
, 698\end{array}$ & $\begin{array}{l}\text {,019 } \\
, 792\end{array}$ & $\begin{array}{l}\text {,151* } \\
\text {,035 }\end{array}$ & $\begin{array}{l}\text {,370** } \\
, 000\end{array}$ & $\begin{array}{l}\text {,350** } \\
, 000\end{array}$ & 1 & & \\
\hline $\begin{array}{l}\text { T4. } \\
\text { Atılımcllık }\end{array}$ & $\begin{array}{l}-, 046 \\
, 523\end{array}$ & $\begin{array}{l}013 \\
, 851\end{array}$ & $\begin{array}{l}\text {,095 } \\
183\end{array}$ & $\begin{array}{l}\text {,354** } \\
, 000\end{array}$ & $\begin{array}{l}, 393 * * \\
, 000\end{array}$ & $\begin{array}{l}\text {,389** } \\
, 000\end{array}$ & 1 & \\
\hline $\begin{array}{lr}\text { T5. } & \text { Risk } \\
\text { Alma } & - \\
\text { Girişimcilik }\end{array}$ & $\begin{array}{l}, 061 \\
, 394\end{array}$ & $\begin{array}{l}165^{*} \\
021\end{array}$ & $\begin{array}{l}-, 089 \\
, 213\end{array}$ & $\begin{array}{l}\text {, } 435^{* *} \\
, 000\end{array}$ & $\begin{array}{l}\text {,278** } \\
, 000\end{array}$ & $\begin{array}{l}\text {,303** } \\
, 000\end{array}$ & $\begin{array}{l}\text {,528** } \\
, 000\end{array}$ & 1 \\
\hline $\begin{array}{l}\text { T6. } \\
\text { Bağımsızlık }\end{array}$ & $\begin{array}{l}- \\
, 210 * * \\
, 003\end{array}$ & $\begin{array}{l}, 036 \\
, 620\end{array}$ & $\begin{array}{l}- \\
, 188 * * \\
, 008\end{array}$ & $\begin{array}{l}169 * \\
, 018\end{array}$ & $\begin{array}{l}195^{* *} \\
, 006\end{array}$ & $\begin{array}{l}087 \\
, 223\end{array}$ & $\begin{array}{l}, 283^{* *} \\
, 000\end{array}$ & $\begin{array}{l}, 233^{* *} \\
, 001\end{array}$ \\
\hline $\begin{array}{l}\text { T7. Genel } \\
\text { Girişimcilik } \\
\text { Eğilimi }\end{array}$ & $\begin{array}{l}-, 055 \\
, 448\end{array}$ & $\begin{array}{l}103 \\
154\end{array}$ & $\begin{array}{l}, 046 \\
, 521\end{array}$ & $\begin{array}{l}631^{* *} \\
, 000\end{array}$ & $\begin{array}{l}, 536 * * \\
, 000\end{array}$ & $\begin{array}{l}, 595 * * \\
, 000\end{array}$ & $\begin{array}{l}, 719 * * \\
, 000\end{array}$ & $\begin{array}{l}\text {,746** } \\
, 000\end{array}$ \\
\hline
\end{tabular}

** Korelasyon ,01 düzeyinde anlamlıdır. * Korelasyon ,05 düzeyinde anlamlıdır. 


\section{Kurtuluş Yılmaz Genç}

Tablo 7, 'iş tecrübesi', 'meslek' ve 'çocuk sayısı' ile girişimcilik eğilimleri ilişkisini ortaya koymaktadır. Buna göre, 'iş tecrübesi' ile 'bağımsızlık' arasında istatistiksel olarak anlamlı, negatif ilişki vardır (,210; ,003). İş tecrübesi arttıkça bağımsızlık eğilimi azalmaktadır. Aksine, 'meslek' ile 'risk alma - girişimcilik' arasında istatistiksel olarak anlamlı, pozitif ilgileşim vardır $(, 165 ;, 021)$. Bu durum, bilgi, deneyim arttıkça risk alma eğiliminin artmasıdır. Bunun da arkasında, bilgiye dayalı 'kendine güven' olduğu söylenebilir. Daha önce bir işi yapmış olma, o işte başarı yeni denemeleri beraberinde getirebilmektedir. Aynı durumun, başarısızıkta da bazı insanlar için geçerli olacağı ifade edilebilir.

İlginç olabilecek bir diğer bulgu da, 'çocuk sayısı' ile 'kararlılık' arasında pozitif $(, 151 ;, 035)$; 'bağımsızlık' arasında da negatif $(-, 188$; ,008) ilişki bulunmasıdır. 'Çocuk sayısı' daha kararlı hareket etmeyi beraberinde getirirken, 'bağımsızlığı' azaltmaktadır. Gündelik hayatı oldukça iyi yansıtan bir sonuç olarak değerlendirilebilir.

Tablo 7'de ortaya konan ilişkilerde göze çarpan bir diğer nokta da, bütünleyici 'genel girişimcilik eğilimi' ile 'dışa dönüklük - kendine güven' (,631; ,000); 'hazır olma - bilgili olma' (,536; ,000); 'kararlılık' (595; ,000); 'atılımclık' (,719; ,000); ve 'risk alma - girişimcilik' (,233; ,001) arasındaki, beklenen, olağan pozitif korelâsyondur. $\quad \mathrm{H}_{3}$ kabul edilmemiştir. $\mathrm{H}_{6}$ reddedilmiştir. $\mathrm{H}_{8}$ reddedilmiştir.

Tablo 8, daha önce bir işletme kurmuş olma ile girişimcilik eğilimleri arasında bir ilişki olmadığı (örneklem dâhilinde) sonucunu yansıtmaktadır $(U=3207$ ve anl.>0,05). Beklenenin aksine, bu iki değişken arasında anlamlı bir ilişkiye ulaşılamamıştır. Daha önce bir işletme kurmuş olmak, elde edilen deneyime, bilgi birikimine dayalı ortaya çıkan bireysel güç ile daha girişimci bir tavır ortaya koymayı kolaylaştıracaktır. Ancak, elde edilen sonuçlar, bu genel öngörüyü desteklememektedir. Bu noktada, örneklem dâhilinde, önceden bir işletme kurmuş olmanın daha temkinli davranma sonucunu doğurduğu değerlendirmesi yapılabilir. Bir başka ifadeyle, hali hazırda girişimci olanların, mevcut kazanımlarını korumaya öncelik verdikleri düşünülebilir. $\mathrm{H}_{5}$ kabul edilmemiştir.

Tablo 8. Daha Önce Bir İşletme Kurmuş Olma ile Girişimcilik Eğilimleri İlişkisi (Mann-Whitney U Testi Sonucu)

\begin{tabular}{lccccc}
\hline $\begin{array}{l}\text { İşletme } \\
\text { Kurmuş } \\
\text { Olma }\end{array}$ & $\mathbf{N}$ & $\begin{array}{c}\text { Ortalama } \\
\text { Aralığı }\end{array}$ & Toplam & $\begin{array}{c}\text { Mann Whitney } \\
\mathbf{U}\end{array}$ & Anl. \\
\hline Evet & 49 & 104,55 & 5123 & 3207 &, 309 \\
Hayır & 145 & 95,12 & 13792 & & \\
\hline
\end{tabular}




\section{Girişimcilik Kurslarına Katılanların Temel Eğilimleri Üzerine Bir Araştırma}

Bir başka değerlendirme konusu, 'evli olup olmama' ile 'girişimcilik eğilimleri ilişkisidir (Tablo 9). Bu çerçevede, bu iki değiş̧en arasında istatistiksel olarak anlamlı bir ilişki yoktur $(U=4560$ ve anl. $>0,05)$. Girişimcilik eğiliminin evli olanlar ile olmayanlar arasında farklılık göstermediği sonucu olağandır. Örneklem dâhilinde, evliliğin girişimciliği engelleyen bir konum olmadığı açıktır. H7 kabul edilmiştir.

Tablo 9. Evli Olup Olmama ile Girişimcilik Eğilimleri İlişkisi (Mann-Whitney U Testi Sonucu)

\begin{tabular}{lccccc}
\hline $\begin{array}{l}\text { Evli Olup } \\
\text { Olmama }\end{array}$ & $\mathbf{N}$ & $\begin{array}{c}\text { Ortalama } \\
\text { Aralığı }\end{array}$ & Toplam & $\begin{array}{c}\text { Mann } \\
\text { Whitney U }\end{array}$ & Anl. \\
\hline Evli & 111 & 97,92 & 10869 & 4560 &, 904 \\
Bekar & 83 & 96,94 & 8046 & & \\
\hline
\end{tabular}

\section{Genel Değerlendirme}

Bulgular arasında yer alan katılımcıların yaşı ile 'dışa dönüklük kendine güven' ve 'kararlılık' arasındaki ilişki, yaşa bağlı olarak ortaya çıkan bilgi birikiminin ya da deneyimin, kişiliği amaçlara ulaşmayı kolaylaştıracak şekilde geliştirdiğini göstermektedir. Buna karşın, günümüzde çok genç yaşlarda, bütün dünyada, çok başarılı girişimcilerin olması iletişim teknolojilerindeki gelişmeye bağı olarak bilgiye kolay ulaşılabilirlik ile açıklanabilir. Günümüzde gençler, özellikle gelişmiş ülkelerde, içlerindeki müthiş dinamizmi çok olumlu bir alana, girişimciliğe yönlendirerek 'yapıcı' olarak 'var olabilmeyi' başarmaktadırlar. Bu durum, girişimcilerin özelikle 'rol modeli' olma durumlarını da güçlendirmektedir. Böylece, hazır bir kimlik sunan girişimcilik, özellikle gençler arasında son derece çekici bir konu haline gelmektedir.

Araştırma kapsamında belirlenen temel değişkenler arasındaki olumlu doğrusallık, bu unsurların girişimciliğin temel bileşenleri olduğu gerçeğini bir kez daha kanıtlamaktadır. Buna göre, 'dışa dönüklük', 'kendine güven', 'kararlılık', 'atılımcılık', 'hazır olma', 'bilgili olma', 'risk alma' gibi özellikler girişimci tutumu güçlendiren temel bileşenlerdendir.

Eğitim düzeyi ile girişimcilik eğilimleri arasında anlamlı bir ilişkinin olmaması, Türkiye'ye ilişkin bir gerçeğin yansıması olarak değerlendirilebilir. Ticaret ve Sanayi Odaları'nın üye profili incelendiğinde her eğitim düzeyinden insanın bir işletmeci ya da girişimci olarak burada yer aldıkları görülebilir. Özellikle, üniversite mezunlarının düşük yüzdesi dikkat çekicidir. Bu durum da, her eğitim düzeyinden insan için girişimciliğin 'varlıklı olma' ve 'var olma'yı kolaylaştıran bir 'çıkış yolu' 


\section{Kurtuluş Yılmaz Genç}

olduğunu kanıtlar niteliktedir. Odaklanmaya dayalı yaratııılık ve yenilikçilik ile fırsatları değerlendirebilme yeteneği eğitim düzeyinden bağımsız olarak insanlara iş yaşamında başarıyı getirebilmektedir.

Veri analizi sonucu ulaşılan bir başka bulgu da, 'iş tecrübesi' ile 'bağımsızlık' arasındaki ters yönlü doğrusallıktır. Bu durum, iş tecrübesinin, başarının paydaşlarla birlikte sağlanabileceğine dair yargıyı güçlendirdiği şeklinde yorumlanabilir. 'Tek başına' değil, birlikte, dayanışma ile 'var olma' elbette günümüzde hayatın her alanında çarpıcı şekilde varlığını gösteren bir durumdur. Bu noktada, işbirliği yapılabilecek herkes ile bu olanağın değerlendirilmesi amaçlanan sonuçlara ulaşmayı çok kolaylaştıracaktır. Bir 'takım çalışması'nın hayatın her alanı için gerekli olduğuna dair bir değerlendirme kolaylıkla yapılabilir.

'Meslek'teki çeşitliliğin, 'risk alma', ve 'girişimcilik'le olumlu doğrusalık göstermesi aynı zamanda denemelerin yeni arayışları da desteklemesi ile açıklanabilir. 'İşin inceliklerini daha çok öğrenme' ile 'giderek daha çok işin inceliklerini öğrenme' arasında bir ilişkinin varlığından söz edilebilir.

Çocuk sayısı ile girişimcilik değişkenleri arasında nasıl ilişki kurulabilir? Bu konu daha çok psikolojik yönü ile değerlendirilmelidir. Çocuğun, paylaşımı ve sorumluluğu artırdığı açıktır. Yine, çocuğun yeni bir sosyalleşme sürecini başlattığı da söylenebilir. Anne ya da baba olan insanların 'birlikte' davranma ya da ortak hareket etme eğilimlerinin güçleneceği dolayısıyla bağımsızlık yönündeki tercihlerinin ya da tavırlarının azalacağı yönünde bir çıkarımda bulunulabilir. Bu durum aile içi sosyalleşme ile de açıklanabilir. Ebeveyn olan insanların aile içinde ortaya çıkacak ortak görüş temelinde daha kararlı hareket etmeleri doğaldır.

Ulaşılan sonuçlara göre, daha önce bir işletme kurmuş olma, örneklem dâhilinde, girişimcilik eğilimlerini etkilememektedir. Bu durum, girişimciliğe ya da işletmeciliğe yeni adım atanların bu yöndeki eğilimlerinin yüksekliğini de ortaya koymaktadır ya da bunun da bir sonucudur. Bu iki durumun birbirini dengelediği açıktır. Daha önce bir işletme kurmuş olma, olumlu ya da olumsuz tecrübeye dayalı olarak, başarı olasılığını artıran bir durum olarak değerlendirilmekte ve özellikle destekleme programlarında bir tercih nedeni olabilmektedir. Buna karşın, deneyim olmasa da, bilgi, yaratıcılık ve bunun sonucu olarak yenilikçilik, risk alma ve fırsatları saptayabilmeye dayalı bir 'yeni' girişimciliğin de başarı olasılığının çok yüksek olduğu açıktır.

Son olarak, katıımcıların medeni durumu ile girişimcilik eğilimleri arasında bir ilişki bulunmadığı yönündeki sonuç, yine beklenen bir 


\section{Girişimcilik Kurslarına Katılanların Temel Eğilimleri Üzerine Bir Araştırma}

bulguyu yansıtmaktadır. Kaldı ki, girişimcilik çok farklı sosyal kesimlerden, çok farklı hayat tecrübesine sahip, evli ya da bekâr her insanın var olabileceği bir alandır. Buna karşın, evliliğin risk alma eğilimini azaltan bir etkisi olabilir. Öte yandan, zaman zaman ekonomik zorunluluklar evlilik durumunda girişimcilikle ilgili risk alma eğilimini daha da artırabilir.

\section{SONUÇ}

Bu çalışmada, girişimcilik kursuna katılanlardan oluşan bir örneklem üzerinde geçekleştirilen bir araştırma ile katıımcıların girişimcilik eğilimi düzeyleri, hangi özelliklerin öne çıktığı ve bunların demografik bilgilerle ilişkisi ortaya konmuştur. Buna göre, ilgili eğilimler altı esas değişken kapsamında değerlendirilmiştir: Dışa dönüklük - kendine güven, hazır olma - bilgili olma, kararlıık, atılımcılık, risk alma - girişimcilik, bağımsızlık. Bu değişkenler arasında bütünsel olarak yüksek düzeyli pozitif ilgileşim vardır.

Yine, veri analizi sonucunda katılımcıların yaşı ile 'dışa dönüklük kendine güven' ve 'kararlıık' arasında pozitif ilişki bulunmuştur. Yine, iş tecrübesiyle 'dışa dönüklük - kendine güven', 'kararlıık' ve 'atıımcılık' arasında istatistiksel olarak anlamlı pozitif ilgileşim vardır. Buna karşın, eğitim düzeyi ile girişimcilik arasında anlamlı ilişki olmadığı görülmüştür. Diğer taraftan, 'iş tecrübesi' ile 'bağımsızlık' arasında istatistiksel olarak anlamlı, negatif ilişki vardır. Aksine, 'meslek' ile 'risk alma - girişimcilik' arasında istatistiksel olarak anlamlı, pozitif ilgileşim vardır. Göze çarpan bir bulgu, 'çocuk sayısı' ile 'kararlılık' arasında pozitif; 'bağımsızlık' arasında da negatif doğrusallık bulunmasıdır. Yine, 'daha önce bir işletme kurmuş olma' ile girişimcilik eğilimleri arasında istatistiksel olarak anlamlı bir ilişki olmadığı görülmüştür. Son olarak, medeni durum ile girişimcilik eğilimleri arasında bir ilgileşim olmadığı sonucuna ulaşılmıştır.

\section{Öneriler}

Sonraki çalışmalarda, araştırmacılar girişimci adaylarının temel eğilimlerini ülkenin farklı bölgelerinde gerçekleştirecekleri araştırmalarla ve daha geniş evren ve örneklemden elde edecekleri veri kümesiyle ortaya koymalıdırlar. Araştırmacılar yine, dışa dönüklük - kendine güven, hazır olma - bilgili olma, kararlılık, atılımcılık, risk alma - girişimcilik ve bağımsızlık ile girişimciliğe başlama eğilimi ve girişimcilikte başarı arasındaki ilişkilere odaklanmalıdırlar. 


\section{Kurtuluş Yılmaz Genç}

\section{Yönetsel Çıkarımlar}

Girişimcilik eğilimleri ile ilgili değerlendirmeler özellikle küçük ve orta büyüklükte işletmelerin yeni ortak alımlarında ya da eleman alımlarında da önemlidir. Buna göre, kişilerin hangi düzeyde söz konusu eğilimlere sahip olduklarına ilişkin yapılacak bir çalışma, ortak alınan kişinin doğru kişi olması yönündeki çabayı destekleyebilecektir. Benzer şekilde, hayatın her alanında girişimci özellikler gösteren ya da kişiliğinde güçlü bir şekilde söz konusu eğilimleri barındıran bir kişinin işe alımı da hem bireysel hem de örgütsel performansı yüksek olaslıkla artıracaktır. $\mathrm{Bu}$ çerçevede, işletme yöneticilerinin ve insan kaynakları yönetimi uzmanlarının işe alımlarda benzer testleri yapmaları önerilebilir.

Benzer şekilde, girişimcilik eğitimi veren kuruluşların kursiyer kabul etme sürecinde girişimcilik eğilimi yüksek olan kişilere öncelik vermeleri söz konusu faaliyetlerin daha verimli olmasını sağlayacaktır. Yine, devletin maddi destek sağlama aşamasında benzer bir ölçütü öne çıkarıp, yukarıda ifade edilen niteliğe daha çok sahip kişilere daha kısa sürede daha fazla destek sağlaması da elde edilen sonuçları daha başarılı kılabilir.

\section{KAYNAKÇA}

Ahmetoglu, G., Leutner, F., Chamorro-Premuzic (2011). EQ-nomics: Understanding the Relation Between Individual Differences in Trait Emotional Intelligence and Entrepreneurship. Personality and Individual Differeneces, 51, 1028-1033.

Akhtar, A., Topping, K. J., Tariq, R. H. (2011). Entrepreneurial Attitudes among Potential Entrepreneurs. Pakistan Journal of Commerce and Social Sciences, 5(1), 12-46.

Beaver, G. (2002). Small Business, Entrepreneurship and Enterprise Development. England: Pearson Education Limited.

Dönmez Polat, D. (2011). Girişimcilik Motivasyonu ve İşletme Yenilikçiliği Arasındaki İlişkinin Araştırılmasına Yönelik Turizm İşletmelerinde Bir Araştırma. Girişimcilik ve Kalkınma Dergisi, 6(2), 227-254.

Erdoğan, Z. (2012). Girişimcilik ve KOBİler: Kavramlar, Sorunlar ve Çözüm Önerileri. Bursa: Ekin Yayınevi.

İrmiş, A., Durak, İ., Özdemir, L. (2010). Girişimcilik Kültürü: Anadolu Girişimciliğinden Örnekler. Bursa: Ekin Yayınevi.

Hatten, T. S. (1997). Small Business: Entrepreneurship and Beyond. USA: Prentice- Hall, Inc.

Kahya, C., İmamoğlu, İ. K. (2013). Sosyo-Dempgrafik Özellikler ve Girişimcilik İlişkisinin Yerel Kalkınma Bağlamında Değerlendirilmesi 


\section{Girişimcilik Kurslarına Katılanların Temel Eğilimleri Üzerine Bir Araştırma}

(Bayburt İli Örneği). Akademik Bakış Dergisi (Uluslararası Hakemli Sosyal Bilimler E-Dergisi), 38, 1-14.

Karabulut, A. T. (2009). Üniversite Öğrencilerinin Girişimcilik Özelliklerini ve Eğilimlerini Belirlemeye Yönelik Bir Araştırma. Marmara Üniversitesi İ.̇̇.B.F. Dergisi, 26(1), 331-356.

Lee, J. (1999). Impact of Culture on Entrepreneurship. AAM Journal, $4(2), 1-22$.

Megginson, W. L., Byrd, M. J., Emeritus Megginson, L. C. (2000). Small Business Management: An Entrepreneur's Guidebook. Third Edition. USA: Irwin McGraw-Hill.

Müftüoğlu, T., Durukan, T. (2004). Girişimcilik ve KOBİler. Ankara: Gazi Kitabevi.

Okhomina, D. (2015). Entrepreneurial Orientation and Psychological Traits: The Moderating Influence of Supportive Environment. Journal of Behavioral Studies in Business. http://www.researchgate.net/publication/242748294

Stefanovic, I., Rankovic, L., Prokic, S. (2011). Entrepreneurs' Motivational Factors: Empirical Evidence From Serbia. Serbian Journal of Management, 6(1), 73-83.

Taşkın, E. (2012). Başarılı Girişimcilerin Ortak Özellikleri. Girişimcilik ve KOBİLER: Kavramlar, Sorunlar ve Çözüm Önerileri. Editör: Prof. Dr. B. Zafer Erdoğan; içinde. Bursa: Ekin yayınevi.

Tiryaki, A. (2012). İktisat Teorisinde Girişimcilik. Girişimcilik ve KOBİLER: Kavramlar, Sorunlar ve Çözüm Önerileri. Editör: Prof. Dr. B. Zafer Erdoğan; içinde. Bursa: Ekin yayınevi.

Topkaya, Ö. (2013). Tarihsel Süreçte Girişimcilik Teorisi: Girişimciliğin Ekonomik Büyüme ve İstihdam Boyutu. Girişimcilik ve Kalkınma Dergisi, 8(1), 29-54.

Veccio, R. P. (2003). Entrepreneurship and Leadership: Common Trends and Common Threads. Human Resource Management Review, 13, 303-327.

Yurtseven, H. R. (2007). Girişimcilik: Küçük Bir İşletme Kurmak ve Yönetmek. Ankara: Detay Yayıncilık.

Uluköy, M., Demireli, C., Kahya, V. (2013). KOSGEB Girişimcilik Kurslarına Katılan Katıımcıların Girişimcilik Profiline Yönelik Bir Alan Araştırması. Girişimcilik ve Kalkınma Dergisi, 8(2), 79-96.

www.marmaragirisim.com 